\title{
Some New Challenges before Indian Democracy and Present Government
}

\author{
Dr. Bina Rai \\ Assistant Professor (Political Science), R.G. (P.G.) College, Meerut
}

\begin{abstract}
India has been a democracy for over six decades. In this time it has achieved some remarkable successes but also failed in significant ways. While economic growth has been rapid over recent decades, this has not translated into greater welfare for the majority of the Indian population. Generally the political system of Third World states is known for political instability, chaos, dispute and so on. Most of the states of the Third World are struggling for a stable political system. Although most of them begin their government with democracy, a very few can sustain on that system. But there is one exceptional and surprising state named India bearing all qualities of Third World States able to keep on her political system successfully.
\end{abstract}

Keywords: Communalism, Corruption, Insurgency, Internal Security, Pseudo-Perverted Democracy

\section{Introduction}

In 1959, the American social and political scientist Seymour Martin Lipset, wrote: The more well-to-do a nation, the greater the chance that it will sustain democracy." A century earlier, in 1861, the British political theorist and philosopher J. S. Mill had written in his treatise Considerations on Representative Government: Free institutions are next to impossible in a country made up of different nationalities. It is in general a necessary condition for free institutions that the boundaries of government should coincide in the main with those of nationalities. If Lipset and Mill were right, than something wrong with Indian democracy, because there would be no such thing as India's democracy.

India is the world's second most populous country. Moreover India's working age population is expected to steadily rise, and by 2035 about $68 \%$ of Indians are expected to be in this category (15-64 years). A demographic dividend beckons India, but with a huge -if' - if the nation is able to properly educate and train its young people, ensure standards of public health that enable society to realize its productive potential, and generate the magnitude and array of employment opportunities that can make India the world's most populous developed democratic country two decades from now. India is also famously a land of contrasts and contradiction. Confounding Lipset, during the three decades in which India built and consolidated its democracy after emerging as a sovereign county in 1947 in an impoverished, virtually pauperized condition from nearly two centuries of colonialist occupation and systemic, rapacious exploitation of its people and resources. While India has evolved over the past six decades as a very robust democracy, in some ways unique in the annals of the contemporary world given the pitfalls of poverty, inequality, and diversity, India's democracy is simultaneously, still in the making or a - ork in progress" a moving, churning object rather than a substance that has achieved some sort of end state. That is precisely what makes the sage of India's democracy in the early twenty first century so fascinating.

The paradox of our times is that we hail the victory of democracy while lamenting the fact that in many countries parliament - the central institution of democracy - is facing a crisis of legitimacy. The executive branch dominates the agenda, international cooperation and globalization have led to decision making that lacks democratic control, and people question whether current political processes are really able to produce parliaments that can represent their interests in all their diversity. The early years of the twenty-first century have witnessed a marked paradox. On the one hand democracy, both as an ideal and as a set of political institutions and practices, has triumphed in most countries of the world. As the outcome statement of the 2005 UN World Summit declared, democracy is a universal value" which does not belong to any country or region'. On the other hand, these years have also seen a considerable disillusionment developing with the results of democracy in practice, one that is shared by citizens of the old" democracies as much as by those of the new and emerging' ones. Parliaments today have a key role in addressing this paradox. As the central institution of democracy, they embody the will of the people in government, and carry all their expectations that democracy will be truly responsive to their needs and help solve the most pressing problems that confront them in their daily lives. As the elected body that represents society in all its diversity, parliaments have a unique responsibility for reconciling the conflicting interests and expectations of different groups and communities through the democratic means of dialogue and compromise.

India is attempting a transformation few nations in modern history have successfully managed: liberalizing the economy within an established democratic order. It is hard to escape the impression that market interests and democratic principles are uneasily aligned in India today. The Indian experience is different on all three counts. India adopted universal suffrage at the time of independence, long before the transition to a modern industrialized economy began. The country does not have an extensive welfare system, although it has made a greater effort to create one of late. And, defying democratic theory, a great participatory upsurge has marked Indian politics, a phenomenon that is only beginning to be understood by scholars and observers: since the early 1990s, India's plebeian orders have participated noticeably more in elections than its upper and middle classes. 


\section{International Journal of Science and Research (IJSR) \\ ISSN (Online): 2319-7064 \\ Index Copernicus Value (2013): 6.14 | Impact Factor (2014): 5.611}

At the time, the Indian National Congress government was embroiled in several high-profile corruption scandals, and ordinary government business had essentially stopped. Bureaucrats and ministers sat on files, afraid to approve anything that might get them in trouble. India had gone from being the world's most promising emerging market to a dysfunctional mess.

Last May, a frustrated, tired nation voted in droves for a regime change and a tough new prime minister: Narendra Modi.In the wake of Narendra Modi's overwhelming victory in India's recent elections, commentators have noted the many, daunting challenges facing the new prime minister of the world's most populous democracy.

\section{Challenges}

1. Flawed General Perception \&Futility of the Present Reform Efforts: Selfishness, Moral-Decay, and Reassuring India's Religious Minoritiesetc. are generally considered as the causes of our society's degeneration. That is because we encounter them in our day-to-day life and also because we are constantly brainwashed/conditioned thus by our demoralized and institutionalized intelligentsia and media who do not dare to or are not capable to look further than their nose. But a deeper analysis would prove that they are really just symptoms produced by the degeneration. Even the malfunction of the political parties and other institutions, such as the bureaucracy, security agencies, media etc., are also not the cause but the manifestations/symptoms of this degeneration. Our political system itself, a PSEUDO-/PERVERTED DEMOCRACY - that produces and promotes a tainted, opportunistic, timid and sycophantic political-leadership-hierarchy, breeds nepotism and perpetuates their reign; that cause the proliferation of political parties; that cause distortion of the people's verdict, instability and incompetence, is the real culprit.

Communalism, an expression of group-selfishness, is subject to all that mentioned above about Selfishness'. That identity can be ideological belief, color, culture, language, caste, religion, region or any other factor. There are 177 million Muslims in India, and all view the new prime minister with suspicion given his past record of support for Hindu nationalism and charges that he failed to stop the 2002 sectarian riots in Gujarat, in which some 1,000 Muslims were killed. The issue of communal violence, though in decline over the long term, remained acutely relevant during the past year, as the country recovered from the 2012 ethnic and religious clashes, in which half a million people were displaced from northeastern states. In September 2013, confrontations between Hindus and Muslims killed 40 people and displaced roughly 40,000 Muslims near the Uttar Pradesh town of Muzaffarnagar. It is a vicious cycle, internally producing ever-increasing acceleration for its degenerative trajectory: i.e. a flawed system producing a vicious leadership to operate it and this self-serving leadership manipulating the system and society to fulfill their own greed, to perpetuate their reign thus causing further degeneration. These traits are normally kept-in-check to a harmless limit, at times even sublimating them to supplement forces of progress, in healthy societies through dexterous management and inspiration by its competent leaders.In Modi's first speech as prime minister-elect, he vowed to work for all Indians. Yet there are still concerns that the Hindu nationalist could stir communal tensions with Muslims, who account for 15 percent of India's 1.2 billion people.

Modi took a tough line in his campaign speeches on illegal immigrants from Bangladesh, a Muslim-majority nation, saying they should have their "bags packed" in case he came to power. He called Hindu refugees from the country "family". Modi denies the accusations and a Supreme Court inquiry did not find enough evidence to prosecute him.

2. Negative Role of Opposition: A democracy operates on the basis that there is room for choice all the way up to the selection of the government. This implies that the legislature, which makes the laws for the country, must itself provide an opportunity for various views to be heard throughout the term. These views should encompass not only those on the government benches, but also those who are opposed to the policies underlying the ways of operation. In other words, lawfully elected representatives of the people must be able to present and discuss alternative policy options even if they are not part of the government and do not have an immediate way of making their plans succeed. In present time opposition plays only negative role in India. Parliamentary sessions end without any legislation. The opposition is the constituent part of Parliament that has the most incentive to use the statutory powers of Parliament to keep the government accountable. In general, if the government commands a large share of the seats with unchecked majority control of the legislature, policy outcomes will reflect the government's position. If the government has relatively fewer seats and the opposition has bargaining resources, then policy making could be shaped by the opposition. The opposition's ultimate sanctioning weapon is that it might be a credible alternative in the next general election. But it can be argued that in the practice of parliamentary opposition in India, the opposition uses Parliament more to impugn the credibility of governments than to exercise accountability for the sake of good governance. Most commentators on Parliament agree that opposition parties in Parliament are relatively weak at generating accountability of government. This is because of a number of structural reasons. First, the effectiveness of the opposition simply depends upon the party composition of Parliament. Where governments have a comfortable majority, there is not much that the opposition can do to censure government. Second, opposition parties are unable to generate new information about government activities that can allow them to take the executive to task. Virtually all opposition parties are reactive rather than proactive, reflecting the extreme organizational weakness of Indian political parties. Third, and unsurprisingly, opposition parties tend to focus on issues judged to have significant immediate political pay-offs rather than on the day-to-day functioning of government. Opposition parties are likely, therefore, to focus more of their attention on political scandals such as financial scams and corruption cases, where they can attack individuals rather than try to force institutional and systemic changes. But perhaps the principal reason that parliamentary opposition parties in India do not

\section{Volume 5 Issue 2, February 2016}




\section{International Journal of Science and Research (IJSR) \\ ISSN (Online): 2319-7064 \\ Index Copernicus Value (2013): 6.14 | Impact Factor (2014): 5.611}

scrutinize the day-to-day functions of government with any seriousness is that political parties in India are flimsy institutions. The opposition in any parliamentary system faces another dilemma. It cannot always oppose the government because it may be blamed for obstructing business; nor can it get away with the credit for enacting legislation. The opposition is most effective when it neither colludes with nor obstructs government. Arguably, this dilemma hampers opposition parties immensely in India's Parliament. There are numerous examples of parties that will often not vote for legislation, not because they disagree with the contents of a particular bill, but because they do not want the government to be able to garner credit for passing it. Given the fragmented nature of parliamentary composition in India in recent years, the pace of legislation is extremely slow, even when there is substantive agreement among political parties. However, in the Indian case, the problem is more acute and has worsened in recent years. Parliament in the public mind is essentially a site for adversarial combat rather than of deliberative clarity.

3. Negative Role of Media: Today is the era of showing off. Everywhere, people believe in being hyper, whether it's a problem or it's a solution. No one's natural. So how can you expect media, the so-called - Repesentatives" of the society to be good and harmonious? Of course not! If you think so, you are mistaken. India, being the world's largest democracy, rests on the media. Keeping this in mind, it becomes important for the media to realize its all-important role and work towards its correct utilization. These channels and newspapers report their own distorted and manufactured version of the news to gain popularity and recognition, even if it means stooping to extremely low levels. Their news is about the rich and the famous and is at the expense of the common man. Who knows what lies beneath? With channel wars so bitter these days, that they would go any length to prove their point. But politics unfortunately is hardly about being a mere" people's representative. It is never that simple. A complex web of intertwined motives and strategies, it is difficult for any politician to come out clean, what with endless media diggings and searches into the candidates past, present and even future. The obvious reaction of any politician to any news story centered on $\mathrm{him} / \mathrm{her}$ is to go into the defensive and play the blame game. Often, they end up making sweeping statements or unsavory comments, which are exaggerated by journalists preferring yellow journalism to an accurate reporting of facts.

Half the politics of politics arises from the way it is reported by the media. Each issue reported about a ruling party manages to arouse the criticism of the opposition. Moreover, most informants of the society are under the influence of powerful politicians, causing biased views, nepotism and even negative campaigning in case of elections. Access to information is essential for a democratic society because it ensures that citizens make responsible, informed choices rather than acting out of ignorance or misinformation and information also serves a checking function. It is well known that media overlaps other functional areas of democracy and governance. For example, support for media may yield results in governance activities, particularly those related to decentralization, anti-corruption, and citizen participation in the policy process.Despite India's vibrant media landscape, journalists continue to face a number of constraints. The government has used security laws, criminal defamation legislation, hate-speech laws, and contempt-of-court charges to curb critical voices on social media as well as traditional media platforms. The election campaign brought heightened attention to the pervasive practice by newspapers and television stations of demanding payment from political candidates in exchange for news coverage. There are also problems with internet freedom. Under India's internet crime law, the burden is on website operators to remove content if requested to do so, and they face possible criminal penalties. Potentially inflammatory books and films are also occasionally banned or censored. Recently Negative Media highlighted intolerance, award return cases communalism, and other issues. Biased media not highlighted government's programme for common people. I want to give example related Chhath Puja, after Diwali many people from Bihar and Uttar Pradesh go home, and New Delhi Railway station suffer huge crowd and causalities. Previous governments closed their eyes, but present government arranged extra trains and give facilities like food and shelter near station. No causalities happened this year but biased media was not highlighted and busy to try criticized government on other issues.

4. Ignorance by People: Our intelligentsia points to ignorant illiterate populace as the basic cause of our degeneration and related problems. They rant: we, Indians, with our illiterate masses, aren't matured for democracy. We elect the wrong persons as our representatives/governors because of the lack of literacy and awareness. For smooth running of our democracy we should educate masses to enlighten them, make them aware of (?)'. Others are prescribing some minimum academic qualification for peoples" representatives to eradicate corruption and inefficiency. Many of them are trying to enhance awareness of the masses on the fronts they think is necessary to regenerate India. So literacy or academic qualification is not the scale of integrity. Education can polish one's talents, give more knowledge about the world, but would not change his innate traits. It can make a crook a sophisticated crook, it would enable one to enter into higher echelons of the society and commit crimes of much higher proportions with a limited impunity using loopholes in the law and society. There may be exemptions but generally they respect the virtuous and aspire for good leaders to lead/govern them. Given a chance with impunity, irrespective of other incentives, they would express this discernment. They have time and again demonstrated this wisdom, and resolve to use it judiciously, while using their voting rights to elect representatives to representative bodies. From where the voters, even with the highest possible awareness, would elect a competent one as his representative when the election arena is full of lackeys, sycophants and vicious manipulators only? If we have to get desirable results after democratic elections, if we intent our voters to elect competent men of integrity and character as their representatives/governors, first we should make sure that the candidates in the fray are of such qualities.

5. Corruption: Modi campaigned on an anti-corruption platform, and the perception of the ruling Congress party as riddled with graft, nepotism, and cronyism played a major 


\section{International Journal of Science and Research (IJSR) ISSN (Online): 2319-7064 \\ Index Copernicus Value (2013): 6.14 | Impact Factor (2014): 5.611}

role in its crushing setback. India was ranked 94 out of 177 countries and territories surveyed in Transparency International's 2013 Corruption Perceptions Index. Though politicians and civil servants are regularly caught accepting bribes or engaging in other corrupt behavior, a great deal of corruption goes unpunished. Domestic and international pressure has led to legislation and activism to counter this trend. While this legislation has had clear positive effects, more than a dozen right-to-information activists have reportedly been killed since late 2009 . Our social leaders and intelligentsia have never been tired of trumpeting corruption as the most prominent cause for the degeneration of our society. It is omnipresent. All of us are somehow related to it as victims, acquiescent or an active practitioner. And most of us are frustrated with its effects on our day-to-day life. Corruption is no longer taboo. It unfortunately even appeals to substantial section of population as a means of making easy money and to get rich quick or to avoid inconveniences. Hence we easily fall prey to this highpitched cry vilifying corruption as the biggest reason of our society's degeneration. It was born with the intelligent human beings. Only its nuances have changed keeping pace with socio-economic changes. All epics and religious books loathe it as we do today, and are full of teachings against it. Even today, many religious, social and political leaders and reformers are, as many before them had been, fighting it at may levels. Most of them are so fanatical on corruption they refuse even to consider any other cause. Others, built their name, fame and followers on anti-corruption platform (Anna Hazare, T .N. Seshan, G. K. Khairnaretc), are afraid of losing them if they admit their platform's futility. Many celebrated political leaders, in their crusade against corruption in their parent parties, had split them, and formed their own parties to lead anticorruption crusade. Some of them even won elections and made their governments promising to eradicate corruption. (V. P. Sing's Janatha-Dal is there as a classic example for everybody to judge the hollowness of such platforms). If corruption was a basic cause, with all these onslaughts against it, it should have been disappeared long ago from this world. To our frustration, not only it has not diminished a bit but has thrived, even baptizing most anti-corruption crusaders into its fold. So, even if admitted it as the cause - just for the sake of argument, what logic is there in hoping that our present day crusaders would succeed to eradicate it today or tomorrow? Competent managers/governors and vigilant citizens in healthy societies are doing it efficiently and silently; while most of our managers/political leaders and even pretentious anticorruption crusaders and intelligentsia acquiesce, facilitate or practice corruption despite their vociferous anticorruption campaigns. By over-emphasizing on corruption, these crusaders are not only wasting their own energy and resources but are also deflecting our attention from the real cause: Perversions of our political system that breed practitioners and promoters of corruption, the tainted sycophants to manage it, are breeding corruption to ridiculously pathetic levels we experience today.

6. Justice and Injustice: The lower levels of the judiciary have been rife with corruption, and most citizens have great difficulty securing justice through the courts. The system is severely backlogged and understaffed, with an estimated 32 million cases pending in lower courts, and 66,000 at the
Supreme Court. This leads to lengthy pretrial detention for a large number of suspects, many of whom remain in jail beyond the duration of any sentence they might receive if convicted. The creation of various fast-track courts to clear the backlog has prompted charges that in some instances due process has been denied.Access to justice is based upon the basic principle that people should be able to rely upon the correct application of law. In actual practice there are several countervailing factors. Some citizens do not know their rights and cannot afford legal aid to advocate on their behalf. A related aspect is fairness of access as some people involved in the legal proceedings and large number of criminal prosecutions are not voluntary participants. The most severe challenge relates to complexity of adjudication as legal proceedings are lengthy and costly and the judiciary lacks personnel and logistics to deal with these matters. For example, at the end of 2006 over 4 million cases (42.42 lakhs) were pending in high courts and over 25 million (2.54 crore) in the sub-ordinate courts in the country. Systematic solutions are, therefore, needed for strengthening access to justice. At the same time ad hoc measures are required to provide immediate assistance to the needy citizens.

7. Centre-state relations:The new federal government will need to mend frayed ties with state governments, who often complain of New Delhi's big brother attitude. A fear of losing fiscal powers forced some states to delay the rollout of a nationwide goods and services tax (GST), which economist estimate would have boosted India's economic growth by as much as 2 percentage points. Opposition from states blocked a plan of the previous government to counter terrorism. Modi needs to act fast as states hold the key for a revival in capital investments, which barely grew last fiscal year as delays in clearances grounded many infrastructure projects. States wield much of the power in approving projects as only a quarter of approvals come from the federal agencies.

8. Insurgency and Internal Security: India's main internal security threat is from Maoists. They have acquired guns, hand grenades and guerrilla war expertise over the years and routinely target security forces and other government officials in areas that contains the country's richest mineral deposits. The Maoist insurgency in several parts of the country remains a serious problem. Among other abuses, the rebels have allegedly imposed illegal taxes, seized food and shelter, and engaged in the abduction and forced recruitment of children and adults. Local civilians and journalists who are perceived to be pro-government have been targeted by the Maoists. The Naxalites movement began in India in the late 1960s as a peasant struggle (in Naxalbari, West Bengal, hence the name Naxalites). It represented the revolutionary stream of Indian Marxism which did not believe that parliamentary democracy would lead to the requisite systemic change and argued for armed struggle instead. Since about 2005-6, the Maoists have become the main target of the Indian state, with thousands of paramilitary forces being poured into the areas where they are strong, and the prime minister repeatedly referring to them as India's biggest security threat. As a consequence, armed conflict is occurring across large parts of central India and is taking several hundred lives on an annual basis. In the state of Chhattisgarh, which is the epicenter of the war, sovereignty 


\section{International Journal of Science and Research (IJSR) \\ ISSN (Online): 2319-7064}

Index Copernicus Value (2013): 6.14 | Impact Factor (2014): 5.611

is contested over large parts of terrain. There are three main perspectives on the Maoist issue. The first, which is the security perspective, equates the Maoists with terrorists. India's home ministry has put out half-page advertisements in all the national newspapers, proclaiming alongside photos of corpses that Naxal are nothing but cold-blooded murderers'. This perspective is blind to the history, ideology, and actual practices of the Maoists. The second, which is the dominant liberal perspective, epitomized by an expert group constituted by the Indian government's Planning Commission, might be labelled the root causes ${ }^{\text {' }}$ perspective. According to this view, poverty and lack of development' (here meaning employment), and the want of primary services like education, are to blame for pushing people to support the Maoists.Maoist cadre are from adivasi or Dalit communities, middle peasants and upper castes play a significant role, especially in leadership positions. The third, which is the revolutionary perspective held by the Maoists themselves and their sympathizers, portrays the movement as a product of structural violence. While they describe people as forced into resistance and armed struggle, there is equally an emphasis on active agency and sacrifice, contrary to the root causes perspective that sees people as mainly passive victims.

9. Rape and Sexual Violence: Rape and other crimes against women are serious problems, and lower-caste and tribal women are particularly vulnerable. The fatal gang rape of a woman on a Delhi bus in December 2012 led to mass demonstrations and drew international attention. General's Special Representative on Sexual Violence in Conflict, voiced strong concern about the prevalence of rape by stating that while bullets, bombs and blades make the headlines, women's bodies remain invisible battlefields'. The government responded by enacting significant legal reforms, and a special court sentenced four men to death for the crime less than nine months later. However, less publicized rape investigations and trials are still lagging nationwide. According to India's most recent National Family Health Survey report - which was released in 2009 and covers the years 2005 and 2006 - 37 percent of married women between ages 15 and 49 have experienced physical or sexual violence at the hands of their husbands. Rape happens everywhere, but India is a particularly tough place to be female. Over $\mathbf{4 0}$ percent of the child marriages in the world take place in India. Sex selective abortions occur there at staggering rates. In 2011, the gender ratio was at its most imbalanced since India's 1947 independence: among children six years old or under, there were only 914 girls per every 1,000 boys. Increases in wealth and literacy have only exacerbated the problem of female feticide. Despite the laws on the books, violence against women is so lightly condemned that over the past five years, India's political parties have nominated 260 candidates waiting to go on trial for various crimes against women. A handful of stateand national-level lawmakers currently in office in India face charges of rape or other crimes against women. India's current public outrage might begin to chip away at this culture of impunity around rape. The Home Secretary has pledged more security on buses, and several fast track courts to adjudicate cases of violence against women, including the recent bus assault, are being set up; this program should be expanded throughout the country.
10. EconomyandUnequal Development:Democracy is a good thing, both intrinsically and instrumentally. Intrinsically, it is a necessary component of the ability of individuals to live freely and autonomously. Instrumentally, it is an institutional guarantee that the policies and laws created by a government will have a reasonable fit with the fundamental interests of the people. Thus democracy is a central determinant of the quality of life, and a central elementinthe ability of men and women to live freely and autonomously as human beings.India is the world's largest country of illiterates and school dropouts, of child and maternal mortality, largest number of stunted and underweight children, and the largest incidence of anemia and $\mathrm{TB}$, and the overwhelming majority of people lacking any of the social benefits that are considered as part of a minimum social safety net. More than 400 million people have less than what by Indian official standards will be considered the barest minimum poverty line. If one takes income inequality, or what is more important, inequality of economic opportunity, Indian inequality is one of the highest in the world, contrary to conventional wisdom. In a country like India inequality of opportunity largely depends on distribution of land, of education, and social identity-a child born in a rural landless adivasi (indigenous) family with very little scope for education will be severely handicapped in her life chances for no fault of her own. Some people think that preoccupation with issues of inequality deflects attention from economic growth which is what mainly alleviates poverty, through creating new and better jobs and generating more public revenue for welfare programmes. Apart from severe deprivations and high inequality of opportunity, another feature of the economy that raises special challenges for social democracy in India is that of all the major developing countries India has the largest informal sector, with 94 per cent of the labor force working there, most of them daily facing the brutal insecurity of no retirement, disability, unemployment or health benefits. Modi biggest challenge will be to revive an economy that is mired in its worst slowdown since the 1980s due to myriad issues such as strained public finances, persistently high inflation, high interest rates and rising bad loans at banks. Public finances are in dire straits as government spending has outpaced revenues. The new administration will immediately need to take a decision on slashing subsidies spending, which is threatening a budget blow-out and a sovereign ratings downgrade. Similarly, the new prime minister has his work cut out to break Asia's third-largest economy out of chronic high inflation, which has forced the central bank to keep interest rates high even as growth sags. Adding to inflationary worries are the prospects of below-average monsoon rains this summer, which could hit farm output and fuel inflation. Modi will need to address the problem of rising bad loans at banks, which have stifled credit flows to corporations. Stressed loans in India - those categorized as bad and restructured total $\$ 100$ billion, or about 10 percent of all loans. India has the second-largest labor force in the world - about 500 million people - but roughly half of them work in the fields, on unproductive small plots of farmland that have been subdivided over generations. While the country has worldclass institutes of technology and management, it also has an abysmal record of giving children a basic education, partly 


\section{International Journal of Science and Research (IJSR) \\ ISSN (Online): 2319-7064}

Index Copernicus Value (2013): 6.14 | Impact Factor (2014): 5.611

because of resistance from rural Indians, who want their children to work rather than go to school. Many businesses also complain that graduates from all but the elite colleges and universities have few usable skills, and can require up to six months of training before being ready for work. Which is why P.M. Modi is casting a much wider net in his quest for economic development - for example, by pushing for hundreds of millions of Indians to open bank accounts, so that the central government can transfer subsidies to them directly rather than through corrupted middlemen. P.M Modi is making a concerted effort to improve India's manufacturing sector - acknowledging, in the process, that economic progress, without jobs, is not the way forward. What we need is not just more production," he has said, but mass production and production by masses."

\section{Conclusion}

In the end, the challenges before democracy is a never ending debate, the more one writes or speaks the lesser it will be. So, what is most important is that we should change our attitudes and mindset. We should try to overcome our self-centered nature. Vibrant democracy with a multilayered pyramid with two doors, each with opposite characters, on each layer. Lowest layer the grass root institutions and the apex of the pyramid with a single seat the highest power, being the seat of its Chief executive $\mathrm{PM} /$ President. Unfortunately those doors in Indian Democracy are tampered to malfunction- they have reversed their function: Attracting and filtering-in the tainted opportunistic sycophantic lackeys only and purging any one exhibiting a grain of competence, integrity and independence during their time at the concerned layer.These attempts will continue forever, motivated by their competent leaders, catalyzing more social evolution and progress in vibrant societies. As the elected body that represents society in all its diversity, parliaments have a unique responsibility for reconciling the conflicting interests and expectations of different groups and communities through the presented in the media. We, nearly thousand million people, boasting inheritance of a rich heritage, are performing much below our potential. We have surely made some progress in the last 50 years. But our achievements, be it in agriculture, industry, technology, arts, sports, diplomacy or any other faculty of life, are far below our potentials when compared with other nations with much less potentials, who had been at par or behind us in 1950s and 1960s. We became a nation of under achievers, under performers, hypocrites, cheats and beggars. We are sending our sons and daughters abroad begging for jobs submitting ourselves to slavery, Government is begging for help - in the form of monetary, technical, diplomatic support from other nations, international organizations and multinationals and from individuals even. Any dream of eliminating communal forces from a society is utopian. What we can try is to keep them in check through dexterous management and inspiring the society to grow to identify with the greater national identity. We blame the Government for the bad condition of our country but if we think deeply, we will find that the people who form Government are from amongst us. So it is the responsibility of our elders to provide children with good moral education, so that they would become responsible citizens of future. Our society needs a paradigm shift instead of creating chaos in the society at the name of misshappenings done by the Government. I think it is much better that we try to change ourselves. We should try to learn from our past mistakes then only we would be able to face challenges before our democracy boldly.

\section{References}

[1] Andersen, Margaret; Taylor, Howard (2008) Sociology: Understanding a Diverse Society, 4th edition. Thompson Learning Inc.

[2] Arch Puddington (Vice President for Research),: India's Democracy Challenge, and Modi's'May 20, 2014 https://freedomhouse.org/blog/indias-democracychallenge-and-modis

[3] AtulKohali: The State and Poverty in India: The Politics of Reform. Cambridge: Cambridge University Press, 1987.

[4] Asghar Ali Engineer,: - Contemporary Challenges to Secularism and Democracy - A Religious Response", April

$1-15$,

2005,http:/www.rightlivelihood.org/fileadmin/Files/PD F/Literature_Recipients/Engineer__Agnivesh/Engineer -_Contemporary_challenges.pdf

[5] Blau, Judith; Moncada, Alberto (2005) Human Rights: Beyond the Liberal Vision, Rowman\& Littlefield Publishers, Inc.

[6] De Haan, Jakob, and Clemens L. J. Sherman, -Ne Evidence on the Relationship between Democracy and Economic Growth. Public Choice 86 (1-2).

[7] Goonesekere, Savitri (2004) Violence, Law and Women's Rights in South Asia, SAGE PublicationsIndia.

[8] J. Huysmans, Security! What do you mean? From Concept to Thick Signifier', European Journal of International Relations, 1998, 4(2)

[9] Md. Manzurul Karim: The political System of India: An Example of a Sustainable Democracy. International Journal of Humanities and Social Science Invention ISSN (Online): 2319 - 7722, ISSN (Print): 2319 - 7714 www.ijhssi.org Volume 2 Issue $1 \|$ January. 2013.

[10] Narayanan Madhavan, India's Band of Billionaires Biggest in Asia', Hindustan Times, 10 March 2007,http://www.hindustantimes.com/India-s-band-ofbillionaires-is-the-biggest-in-Asia/Article1-209306. Aspx.

[11] NANDINI SUNDAR: Insurgency, Counter-insurgency, and Democracy in Central India http://burawoy.berkeley.edu/Public\%20Sociology, \%20 Live/Sundar/Insurgency, \%20Counterinsurgency $\% 20 \& \% 20$ Democracy.pdf

[12] Norman D Palmer.: The Indian Political System", Boston: Hougton Mifflin Company, 1961.

[13] Pranab Bardhan:Inequality, Inefficiency, and the Challenges for Social Democracy in India's Economic Transition.

[14] Rajni Kothari, (Politics in India, Orient Longman Ltd., New Delhi, 1970 and Rethinking Democracy, Orient Longman Ltd., New Delhi, 2005).

[15] Varshney Ashutosh: -Cłllenges before Indian Democracy, India's Democratic Challenge', Foreign Affairs, 86 (2), March-April, 2007.

\section{Volume 5 Issue 2, February 2016}


[16] The Hindu, 15 July 2010, http://www.hindu.com/2010/07/15/stories/20100 71557350100.htm

[17]For the first phase of the Naxalites movement, see ManorajanMohanty, Revolutionary Violence: A Study of the Maoist Movement in India (New Delhi: Sterling 1977); Sumanta Banerjee, India's Simmering Revolution: The Naxalites Uprising (New Delhi: Select Book Service Syndicate, 1984); for the more recent phase in Andhra Pradesh, see Committee of Concerned Citizens (CCC), Third Report: A Detailed Account of the Committee During the Five Years to Intervene in the Climate of Turmoil and Social Violence in Rural Andhra Pradesh (Hyderabad: CCC, 2002); CCC, Negotiating Peace, (Hyderabad, 2006); Bela Bhatia, The Naxalites Movement in Central Bihar', Economic and Political Weekly (henceforth EPW), 9 April 2005. See also articles in the special section on the Maoist Movement in India', EPW, 22-8 July 2006, and response by Azad, Maoists in India: A Rejoinder', EPW, 14 October 2006. 